\title{
KEY SECTORS PERSPECTIVE IN SELECTING OPTIMAL BIOLOGICAL NUTRIENT REMOVAL TECHNOLOGIES FOR SEWAGE TREATMENT IN THE PHILIPPINES
}

\author{
Regina Damalerio ${ }^{1,2}$, Carla Mae Pausta ${ }^{1,2}$, Ramon Christian Eusebio ${ }^{3}$, Michael \\ Angelo Promentilla ${ }^{1,2}$, Aileen Orbecido ${ }^{1,2}$, Liza Patacsil ${ }^{4}$, and Arnel Beltran ${ }^{1,2}$ \\ ${ }^{1}$ Chemical Engineering Department, De La Salle University, Manila, Philippines, Tel: +63285244611 loc. \\ 218, e-mail: regina_damalerio@dlsu.edu.ph, carla_pausta@dlsu.edu.ph,michael.promentilla@dlsu.edu.ph, \\ aileen.orbecido@dlsu.edu.ph, arnel.beltran@dlsu.edu.ph \\ ${ }^{2}$ Center for Engineering Sustainable and Development Research, De La Salle University, Philippines, Tel: \\ +63285244611 loc.157, e-mail: regina_damalerio@dlsu.edu.ph, carla_pausta@dlsu.edu.ph, \\ michael.promentilla@dlsu.edu.ph, aileen.orbecido@dlsu.edu.ph, arnel.beltran@dlsu.edu.ph \\ ${ }^{3}$ Chemical Engineering Department, University of the Philippines Los Baños, Laguna, Philippines, Tel: \\ +634953623152, e-mail: rpeusebio@up.edu.ph \\ ${ }^{4}$ Chemical Engineering Department, Malayan Colleges Laguna, Laguna, Philippines, Tel: +63498324037, \\ e-mail: lbpatacsil@mcl.edu.ph
}

Received Date: July 29, 2020; Revised Date: September 17, 2020; Acceptance Date: October 21, 2020

\begin{abstract}
The current effluent standards emphasize on the removal of nutrients from sewage, and one solution is for establishments to install biological nutrient removal (BNR) technologies. However, there are several factors to be considered in installing or upgrading the technologies. Hence, the study utilizes two multi-criteria decision analysis (MCDA) tools to determine the important attributes and the optimal technology from the perspective of the academe, regulatory agency, and industry. Calibrated fuzzy analytical hierarchy process (FAHP) calculates the relative importance of the three criteria (implementability, financial, and socio-environmental) and twelve sub-criteria. On the other hand, the grey relational analysis is used to calculate the performance of the four selected alternatives: 3stage Bardenpho $\left(\mathrm{A}^{2} \mathrm{O}\right)$, 5-stage Bardenpho (5BP), sequencing batch reactor (SBR), and membrane bioreactor (MBR). Combining the results of calibrated FAHP and GRA provided the overall ranking of alternatives. Results showed that each sector prioritized different factors in the selection of the optimal BNR technology. The academe considers socio-environmental $(0.43)$ as the most preferred criterion, while the regulatory agency and industry consider financial (0.36) and implementability (0.57), respectively. Overall, the three sectors agreed that the sequential batch reactor (SBR) is the optimal BNR technology $(\mathrm{GRG}=0.69-0.79)$.
\end{abstract}

Keywords: Biological nutrient removal, Fuzzy analytic hierarchy process, Grey relational analysis, Multi-criteria decision analysis, Sewage treatment

\section{Introduction}

Expanding sewerage networks and providing wastewater treatment systems remain challenging for water utility agencies in the Philippines $[1,2]$. Due to rapid urbanization of cities and low investments, only few households are connected to sewerage networks and only $10 \%$ of wastewater are treated prior to disposal $[1,2]$. Untreated wastewater is the main 
cause of water pollution as it carries excessive amount of nutrients (nitrogen and phosphorus) to water bodies [1-3]. It promotes the growth of algal blooms which depletes the oxygen source essential to aquatic life [3,4]. With polluted waters, there will be limitations in providing sufficient water supply for various applications to future cities [1, 2]. In 2016, the Department of Environment and Natural Resources - Environmental Management Bureau (DENR - EMB) released an administrative order requiring all establishments to upgrade their treatment facilities in limiting ammonia-nitrogen $\left(\mathrm{NH}_{3}-\mathrm{N}\right)$, nitrate-nitrogen $\left(\mathrm{NO}_{3}-\mathrm{N}\right)$ and phosphates $\left(\mathrm{PO}_{4}{ }^{3-}\right)$ concentrations [5]. To comply with the stringent requirements, stakeholders are considering in upgrading their facilities to biological nutrient removal (BNR) technologies [4].

BNR technologies are cost-effective alternatives which allow microorganisms present in wastewater, under certain conditions, to degrade organic matter [6,7]. For example, nitrifying microorganisms convert ammonia to nitrates in aerobic conditions, while heterotrophic bacteria convert the nitrates to atmospheric nitrogen $\left(\mathrm{N}_{2}\right)$ in anoxic conditions. Polyphosphate-accumulating organisms (PAOs) are facultative bacteria that release phosphates in wastewater while assimilating volatile fatty acids in anaerobic conditions and uptake excessive amount of phosphates in aerobic conditions. Phosphates are then wasted from the system as excess sludge $[6,7]$. There are several studies that investigated the effect of flowrates, tank configuration, chemical addition for food source or phosphate precipitation, and other parameters to optimize the nutrient removal capability [8-10]. However, in the selection of the most suitable BNR technology, the different perspectives among decision makers, and the financial, operational, and socio-environmental aspects are considered to reach a conclusion $[4,11,12]$. This can be solved by utilizing multiple-criteria decision analysis (MCDA) tools which have provided sound analysis in several multiattribute complex problems such as selection of optimal technologies, materials, and suppliers [4, 11-25].

The study presents the application of two MCDA tools to determine the preferred BNR technology of the three sectors (academe, regulatory agency, and industry) for sewage treatment in the Philippines. Calibrated fuzzy analytical hierarchy process (FAHP) determines the relative importance of the attributes while grey relational analysis (GRA) calculates the ranking of alternatives. FAHP, proposed by van Laarhoven and Pedrycz, structures the problem in a hierarchical manner [26]. The topmost level represents the problem statement, followed by criteria and sub-criteria in the intermediate levels, and alternatives in the bottom level [13-15]. FAHP quantifies the ambiguity of the decision makers' value judgements into triangular fuzzy numbers denoted as $\hat{a}_{i j}=\left\langle\mathrm{l}_{\mathrm{ij}}, \mathrm{m}_{\mathrm{ij}}, \mathrm{u}_{\mathrm{ij}}\right\rangle$, where $\mathrm{l}_{\mathrm{ij}}, \mathrm{m}_{\mathrm{ij}}$, and $\mathrm{u}_{\mathrm{ij}}$ are the lower, modal, and upper values, respectively, between attributes $i$ and $j$ [13-15]. Several studies utilized FAHP alone or combined with other MCDA tools in solving environmental-related problems. Tan et al. used FAHP to evaluate three technologies for municipal wastewater treatment based on four criteria (technical, environmental, ease-to-upgrade, and net present value) [13]. Karimi et al. compared the results of using AHP and FAHP in evaluating different aerobic wastewater treatment processes at three criteria levels [15]. Ghassemi and Danesh applied FAHP with technique for order of preference by similarity to ideal solution (TOPSIS) for the selection of the optimal desalination process based on three criteria (environmental, technical, and economical) and ten sub-criteria [16]. On the other hand, Deng proposed utilizing GRA for solving multi-attribute problems with limited and uncertain information [18, 20, 24, 27, 28]. 
There are studies that utilize GRA as a stand-alone tool [17, 20, 28]. However, it provides inaccurate results in assuming equal importance among attributes [29]. Hence, other studies combine GRA with other MCDA tools to capture the preferred attributes of the decision makers [11, 24, 29]. Zeng et al. evaluated four wastewater treatment alternatives based on three criteria and eight sub-criteria by combining AHP-GRA [11]. Pakkar integrated AHP, GRA, and data envelopment analysis (DEA) for appropriate site for disposing nuclear wastes [29]. DEA evaluates the performance of each alternative in both desirable and undesirable scenarios [29]. Pophali et al. applied AHP-GRA in the selection of wastewater treatment for tanneries in India based on three criteria (economic, technical, and administrative), and thirteen sub-criteria [30]. Studies by Eusebio et al. and Ilangkumaran et al. applied FAHP instead with GRA to select the most suitable treatment alternatives [18, 19]. Eusebio et al. used five criteria, namely, energy requirements, land footprint, system efficiency, economic viability, and maturity of technology for the optimal desalination system [18]. Ilangkumaran et al. determined the appropriate wastewater treatment technology based on three criteria and thirteen sub-criteria [19].

\section{Methodology}

The study determines the optimal BNR technology for sewage treatment in the Philippines based on the perspective of three sectors. The difference in the prioritization of several factors is presented with the use of calibrated FAHP and GRA. The methodology of the study is summarized in Figure 1.

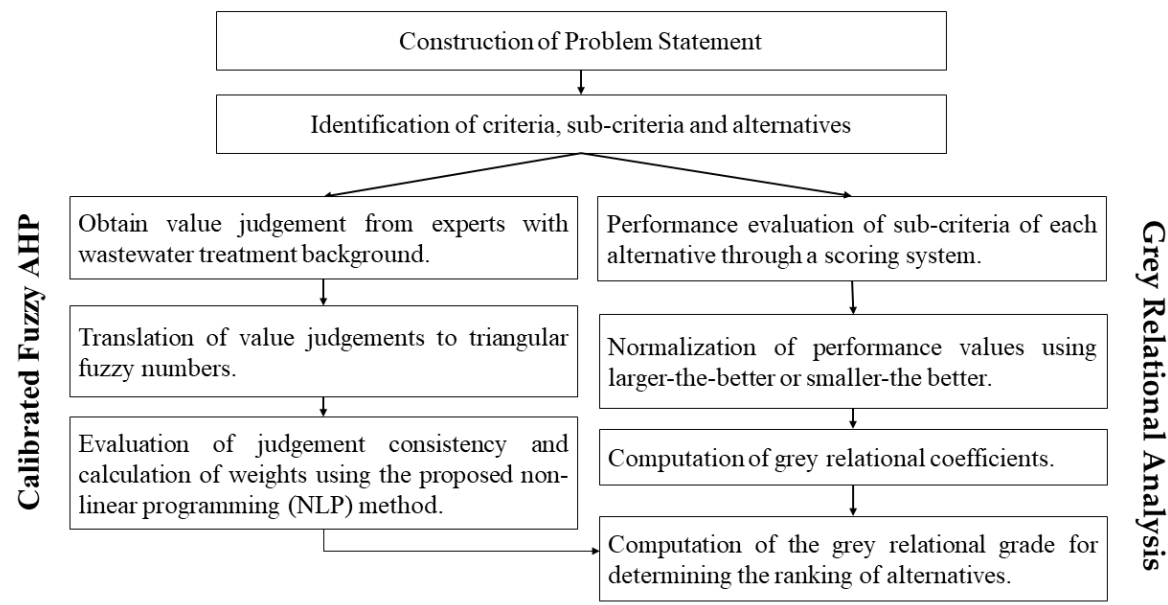

Figure 1. Methodology flow chart.

The hierarchical structure is presented in Figure 2. The topmost level represents the main objective which is to determine the optimal BNR technology for sewage treatment in the Philippines. The criteria and its sub-criteria were determined through literature reviews and focus group discussion with experts on wastewater treatment. The chosen twelve subcriteria were categorized based on three criteria: implementability $\left(\mathrm{C}_{1}\right)$, financial $\left(\mathrm{C}_{2}\right)$, and socio-environmental $\left(\mathrm{C}_{3}\right)$. Lastly, the alternatives are 3-stage phoredox $\left(\mathrm{A}^{2} \mathrm{O}\right), 5$-stage Bardenpho (5BP), sequential batch reactors (SBR), and membrane bioreactors (MBR). The alternatives were selected based on the assessment conducted by Pausta et al. and Promentilla et al. $[4,14]$. Pausta et al. discussed that BNR technologies such as University Cape Town (UCT) and Virginia Initiative Plant (VIP) are least preferred to be installed in 
urban areas in the Philippines [4]. The 3-stage phoredox $\left(\mathrm{A}^{2} \mathrm{O}\right)$ consists of three tanks where wastewater is treated at anaerobic, anoxic, and oxic conditions. Nitrate-rich liquor is recycled from the aerobic zone to the anoxic zone, and activated sludge is recycled back to the anaerobic zone. The 5-stage Bardenpho (5BP) utilizes one anaerobic zone and two simultaneous anoxic and aerobic zones. The rich nitrate liquor from the first aerobic zone is recycled back to the first anoxic zone [6,7]. In membrane bioreactors (MBR), membrane modules in the aeration basins are utilized for separation of solids and pathogenic microorganisms from treated wastewater [7]. Lastly, the sequencing batch reactor (SBR) performs cyclic physical and biological treatment in a single complete-mix reactor [6,7]. The definitions of the criteria and sub-criteria are listed in Table 1.

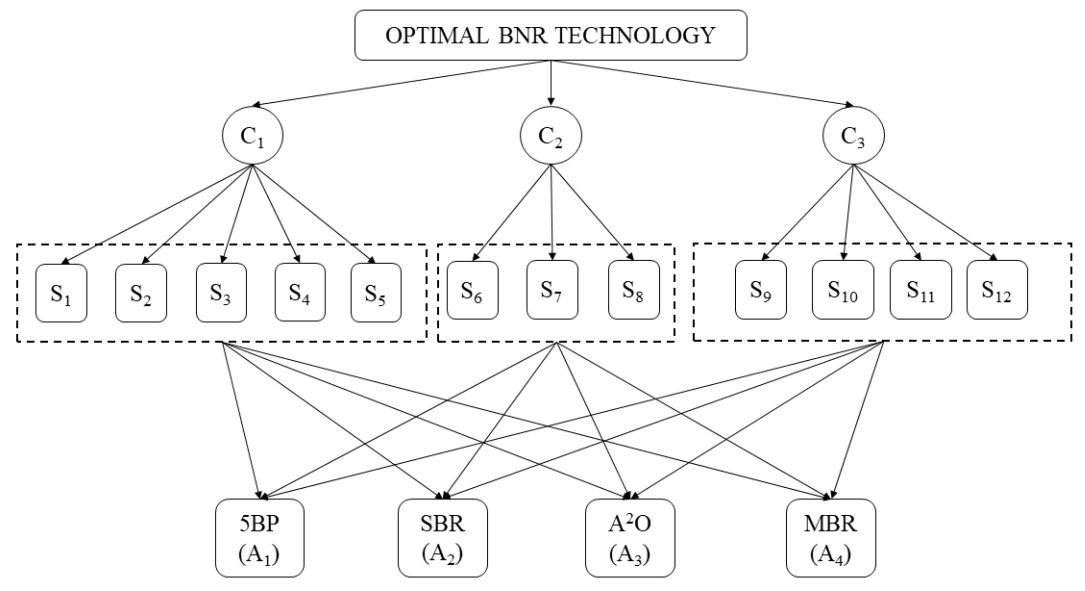

Figure 2. The constructed hierarchical network for optimal selection of BNR technology.

\section{Calibrated Fuzzy Analytical Hierarchy Process}

Experts with wastewater treatment background from the academe, regulatory agency, and industry made pairwise comparisons of the criteria as well as the sub-criteria [18]. The obtained value judgements were converted to corresponding TFNs from Promentilla et al. (see Table 2) [14]. For each sector, the fuzzy value judgements were aggregated into one fuzzy pairwise comparison matrix $\widehat{A}$ using the geometric mean method $[12,14]$. The comparison matrix $\widehat{A}$ is represented as [14]:

$$
\begin{gathered}
\widehat{A}=\left[\begin{array}{cccc}
\langle 1,1,1\rangle & \hat{a}_{12} & \ldots & \hat{a}_{1 n} \\
\hat{a}_{21} & \langle 1,1,1\rangle & \ldots & \hat{a}_{2 n} \\
\vdots & \vdots & \ddots & \vdots \\
\hat{a}_{n 1} & \hat{a}_{n 2} & \ldots & \langle 1,1,1\rangle
\end{array}\right] \\
\text { where } \hat{a}_{i j}=\left\langle l_{i j}, m_{i j}, u_{i j}\right\rangle ; \hat{a}_{j i}=\left\langle\frac{1}{u_{i j}}, \frac{1}{m_{i j}}, \frac{1}{l_{i j}}\right\rangle .
\end{gathered}
$$

The priority weights of the criteria and sub-criteria were calculated using the proposed non-linear programming (NLP) method in LINGO 18.0 software $[12,13,18]$. The NLP method determines the weights while maximizing the judgement consistency $K$ for each comparison matrix. $K$ approaching 1.0 denotes a perfectly consistent judgement $[4,12,13]$. 
Table 1. Definition of Criteria (C) and Sub-Criteria (S)

Criteria (C) / Sub-criteria (S) Definition

Implementability $\left(\mathrm{C}_{1}\right)$

Technical aspect of the technology with regards to the operation and capability of the system

Robustness $\left(\mathrm{S}_{1}\right)$

Ability to withstand or adjust to the changes

Energy requirement $\left(\mathrm{S}_{2}\right)$

Capability of the system to operate with less energy requirement

Ease of operation $\left(\mathrm{S}_{3}\right)$

Complexity of the BNR technology in terms of maintenance and automation

Maturity of technology $\left(\mathrm{S}_{4}\right)$

The readiness of the technology for operation since the technology has been thoroughly studied based on several parameters

Space requirement $\left(\mathrm{S}_{5}\right)$

The land area needed for operating the system

Financial $\left(\mathrm{C}_{2}\right)$

Costs associated with the implementation and operation of the system

Capital cost $\left(\mathrm{S}_{6}\right)$

Investment of the company to install or construct a BNR technology

Operating and maintenance

Incurred cost to maintain a steady operation (energy,

$(\mathrm{O} \& \mathrm{M}) \operatorname{cost}\left(\mathrm{S}_{7}\right)$

Return of investment $\left(\mathrm{S}_{8}\right)$ staff, maintenance, miscellaneous)

Efficiency of the investment to gain profit from the technology with time consideration

Socio-Environmental $\left(\mathrm{C}_{3}\right) \quad$ Perception and acceptance of the people to the installation of BNR technology;

Compliance of the technology based on the standards imposed by the regulatory agency

Nutrient removal efficiency $\left(\mathrm{S}_{9}\right) \quad$ Capability of the technology to achieve the effluent wastewater standards imposed by the DENR

Social acceptability $\left(\mathrm{S}_{10}\right)$

Tariff $\left(\mathrm{S}_{11}\right)$

Perception based on odor, visual, and noise impacts

Willingness of the people to pay additional cost for the adoption of the new technology

Feasibility $\left(\mathrm{S}_{12}\right)$

Marketability of the technology in the community

Table 2. Triangular Fuzzy Number Equivalents for the Linguistic Scale from Promentilla et al. [14]

\begin{tabular}{lcccc}
\multicolumn{1}{c}{ Linguistic Scale } & $\begin{array}{c}\text { Fuzzy } \\
\text { Number }\end{array}$ & $\begin{array}{c}\text { Lower } \\
\text { Bound } \\
\left(\mathbf{l}_{\mathbf{i j}}\right)\end{array}$ & $\begin{array}{c}\text { Modal } \\
\text { Bound } \\
\left(\mathbf{m}_{\mathrm{ij}}\right)\end{array}$ & $\begin{array}{c}\text { Upper } \\
\text { Bound } \\
\left(\mathbf{u}_{\mathrm{ij}}\right)\end{array}$ \\
\hline Equally (EQ) & 1 & 1.0 & 1.0 & 1.0 \\
Slightly More (SM) & 2 & 1.2 & 2.0 & 3.2 \\
Moderately More (MM) & 3 & 1.5 & 3.0 & 5.6 \\
Strongly More (ST) & 5 & 3.0 & 5.0 & 7.9 \\
Very Strongly More (VS) & 8 & 6.0 & 8.0 & 9.5
\end{tabular}

A separate scoring system was developed for experts to evaluate the performance of each alternative based on the twelve sub-criteria. The scoring system determines the desirable attributes or sub-criterion $j$ for each alternative $i$ as shown in Table 3 [18]. 
Table 3. Scoring Sheet Template for the GRA

Criteria/

Score

\begin{tabular}{|c|c|c|c|c|c|c|}
\hline \multirow{2}{*}{\multicolumn{2}{|c|}{ Subcriteria }} & \multirow{2}{*}{\multicolumn{2}{|c|}{2}} & \multirow[b]{2}{*}{3} & \multirow[b]{2}{*}{4} & \multirow[b]{2}{*}{5} \\
\hline & & & & & & \\
\hline \multirow{5}{*}{ 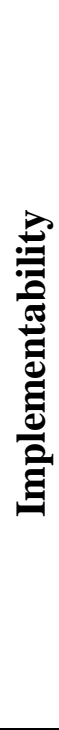 } & Robustness & $\begin{array}{l}\text { Not } \\
\text { flexible }\end{array}$ & $\begin{array}{l}\text { Slightly } \\
\text { flexible }\end{array}$ & Flexible & $\begin{array}{l}\text { Moderately } \\
\text { flexible }\end{array}$ & $\begin{array}{l}\text { Highly } \\
\text { flexible }\end{array}$ \\
\hline & $\begin{array}{l}\text { Energy } \\
\text { Requirement }\end{array}$ & $\begin{array}{l}\text { Very } \\
\text { high energy }\end{array}$ & $\begin{array}{l}\text { High } \\
\text { energy }\end{array}$ & $\begin{array}{l}\text { Medium } \\
\text { energy }\end{array}$ & Low energy & No energy \\
\hline & $\begin{array}{l}\text { Ease of } \\
\text { Operation }\end{array}$ & $\begin{array}{l}\text { Very } \\
\text { difficult }\end{array}$ & Difficult & Easy & Very Easy & Automated \\
\hline & $\begin{array}{l}\text { Maturity of } \\
\text { Technology }\end{array}$ & $\begin{array}{l}\text { Research } \\
\text { stage }\end{array}$ & $\begin{array}{l}\text { Develop- } \\
\text { ment stage }\end{array}$ & $\begin{array}{l}\text { System } \\
\text { improvement }\end{array}$ & $\begin{array}{l}\text { Well- } \\
\text { Established } \\
\text { system }\end{array}$ & $\begin{array}{l}\text { Industrial } \\
\text { application }\end{array}$ \\
\hline & $\begin{array}{l}\text { Space } \\
\text { Requirement }\end{array}$ & $\begin{array}{l}\text { Very } \\
\text { small }\end{array}$ & Small & Medium & Large & $\begin{array}{l}\text { Very } \\
\text { large }\end{array}$ \\
\hline \multirow{3}{*}{ 馬 } & Capital Cost & $\begin{array}{l}\text { Very } \\
\text { high } \\
\text { investment }\end{array}$ & $\begin{array}{l}\text { High } \\
\text { investment }\end{array}$ & $\begin{array}{l}\text { Low } \\
\text { investment }\end{array}$ & $\begin{array}{l}\text { Very } \\
\text { low } \\
\text { investment }\end{array}$ & $\begin{array}{l}\text { No } \\
\text { investment }\end{array}$ \\
\hline & O\&M Cost & $\begin{array}{l}\text { Very } \\
\text { high cost }\end{array}$ & High cost & Low cost & $\begin{array}{l}\text { Very } \\
\text { low cost }\end{array}$ & No cost \\
\hline & $\begin{array}{l}\text { Return of } \\
\text { Investment }\end{array}$ & Very low & Low & Moderate & High & Very high \\
\hline \multirow{4}{*}{ 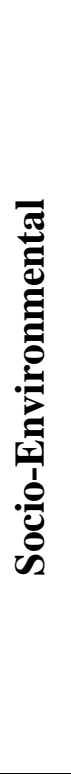 } & $\begin{array}{l}\text { Nutrient } \\
\text { Removal } \\
\text { Efficiency }\end{array}$ & $\begin{array}{l}\text { Low } \\
\text { nutrient } \\
\text { removal }\end{array}$ & $\begin{array}{l}\text { Low to } \\
\text { moderate } \\
\text { nutrient } \\
\text { removal }\end{array}$ & $\begin{array}{l}\text { Moderate } \\
\text { nutrient } \\
\text { removal }\end{array}$ & $\begin{array}{l}\text { Moderate to } \\
\text { high } \\
\text { nutrient } \\
\text { removal }\end{array}$ & $\begin{array}{l}\text { High } \\
\text { nutrient } \\
\text { removal }\end{array}$ \\
\hline & $\begin{array}{l}\text { Social } \\
\text { Acceptability }\end{array}$ & $\begin{array}{l}\text { Not } \\
\text { acceptable }\end{array}$ & $\begin{array}{l}\text { Slightly } \\
\text { acceptable }\end{array}$ & Acceptable & $\begin{array}{l}\text { Moderately } \\
\text { acceptable }\end{array}$ & $\begin{array}{l}\text { Highly } \\
\text { acceptable }\end{array}$ \\
\hline & Tariff & $\begin{array}{l}\text { Not willing } \\
\text { to pay }\end{array}$ & $\begin{array}{l}\text { Slightly } \\
\text { willing } \\
\text { to pay }\end{array}$ & $\begin{array}{l}\text { Willing } \\
\text { to pay }\end{array}$ & $\begin{array}{l}\text { Moderately } \\
\text { willing } \\
\text { to pay }\end{array}$ & $\begin{array}{l}\text { Very } \\
\text { willing } \\
\text { to pay }\end{array}$ \\
\hline & Feasibility & $\begin{array}{l}\text { Very } \\
\text { difficult to } \\
\text { market and } \\
\text { implement }\end{array}$ & $\begin{array}{l}\text { Difficult to } \\
\text { market and } \\
\text { implement }\end{array}$ & $\begin{array}{l}\text { Easy to } \\
\text { market and } \\
\text { implement }\end{array}$ & $\begin{array}{l}\text { Moderately } \\
\text { easy to } \\
\text { market and } \\
\text { implement }\end{array}$ & $\begin{array}{l}\text { Very easy to } \\
\text { market and } \\
\text { implement }\end{array}$ \\
\hline
\end{tabular}

The raw data for each group were aggregated by average and were normalized using either larger-the-better or smaller-the-better attributes presented in Equation 2 and 3 [28]:

$$
x_{i j}=\frac{y_{i j}-\operatorname{Miny}_{i j}, i=1,2, \ldots, m}{\operatorname{Max}\left\{y_{i j}, i=1,2, \ldots, m\right\}-\operatorname{Miny}_{i j}, i=1,2, \ldots, m} \text { for } i=1,2, \ldots, m \text { and } j=1,2, \ldots, n
$$




$$
x_{i j}=\frac{\operatorname{Max}\left\{y_{i j}, i=1,2, \ldots, m\right\}-y_{i j}}{\operatorname{Max}\left\{y_{i j}, i=1,2, \ldots, m\right\}-\operatorname{Miny}_{i j}, i=1,2, \ldots, m} \text { for } i=1,2, \ldots, m \text { and } j=1,2, \ldots, n
$$

where $\mathrm{y}_{\mathrm{ij}}$ and $\mathrm{x}_{\mathrm{ij}}$ are the performance value and comparability sequence or sub-criterion $j$ of alternative $i$, respectively $[18,28]$. Equation 3 is adopted for the data on space requirement since it is desirable if the technology can be installed in limited space, while Equation 2 is adopted for the remaining sub-criteria. The comparability sequence $\mathrm{x}_{\mathrm{ij}}$ denotes the approximate characteristic of sub-criterion $j$ of alternative $i$ with reference to the ideal value $\left(\mathrm{x}_{0 \mathrm{j}}\right)$ of $1.00[18,28]$. It implies that $\mathrm{x}_{\mathrm{ij}}$ values approaching or equal to 1.0 are considered as strong or best attributes of alternative $i[18,28]$.

The grey relational coefficients were calculated using the following equations [28]:

$$
\begin{gathered}
\gamma\left(x_{0 j}, x_{i j}\right)=\frac{\Delta_{\text {min }}+\delta \Delta_{\min }}{\Delta_{i j}+\delta \Delta_{\text {max }}} \text { for } i=1,2, \ldots, m \text { and } j=1,2, \ldots, n, \\
\Delta_{i j}=\left|x_{0 j}-x_{i j}\right|, \\
\Delta_{\text {min }}=\operatorname{Min}\left\{\Delta_{i j}, i=1,2, \ldots, m ; j=1,2, \ldots, n\right\}, \text { and } \\
\Delta_{\text {max }}=\operatorname{Max}\left\{\Delta_{i j}, i=1,2, \ldots, m ; j=1,2, \ldots, n\right\},
\end{gathered}
$$

where $\delta$ is the distinguishing coefficient that can be varied from 0 to 1 . The reference or ideal sequence $\left(\mathrm{x}_{0 \mathrm{j}}\right)$ equal to 1 and distinguishing coefficient of 0.50 were applied in the study $[18,20,28]$.

Lastly, the ranking of alternatives was determined by computing the grey relational grade (GRG) in Equation 8 [18, 20, 28]. This was carried out by combining the global weights $\left(\mathrm{w}_{\mathrm{j}}\right)$ from the calibrated FAHP and the computed grey relational coefficients from Equation 4. The alternative with the highest GRG is the optimal BNR technology for sewage treatment in the Philippines.

$$
\mathrm{T}\left(X_{0}, X_{i}\right)=\sum_{j=1}^{n} w_{j} \gamma\left(x_{0 j}, x_{i j}\right) \text { for } i=1,2, \ldots, m
$$

\section{Results and Discussion}

The academe, regulatory agency, and industry are responsible for the implementation and development of BNR technologies in the country. Each sector has preferred criteria and subcriteria based on generated weights using the NLP method in Tables 4-6 [12, 13].

The academe provides insights based on literature and research. Based on the results, socio-environmental (0.4286) is the most important criterion, followed by financial (0.2991) and implementability (0.2723). Feasibility (0.1428) ranked the highest among other sub-criteria, implying preference on technologies that can be possibly operated locally given several constraints. Space requirement (0.0721) ranked highest under implementability and this attributed to the limited land area for installation, especially in urban areas. Lastly, return 
of investment (0.1334) ranked highest under financial. Since BNR technologies will be the trend for wastewater treatment in the Philippines, it could encourage stakeholders to invest for compliance with the current effluent standards. In addition, a high return of investment can prompt stakeholders to support research activities on BNR technologies.

Table 4. The Weights of Criteria and Sub-criteria for the Academe

\begin{tabular}{cccc} 
Criteria & Weight & Sub-Criteria & Weight \\
\hline \multirow{3}{*}{ Implementability $\left(\mathrm{C}_{1}\right)$} & \multirow{2}{*}{0.2723} & Robustness $\left(\mathrm{S}_{1}\right)$ & 0.0503 \\
& & Energy Requirement $\left(\mathrm{S}_{2}\right)$ & 0.0659 \\
& & Ease of Operation $\left(\mathrm{S}_{3}\right)$ & 0.0435 \\
& & Maturity of Technology $\left(\mathrm{S}_{4}\right)$ & 0.0404 \\
Financial $\left(\mathrm{C}_{2}\right)$ & \multirow{2}{*}{0.2991} & Space Requirement $\left(\mathrm{S}_{5}\right)$ & 0.0721 \\
\hline & & Capital Cost $\left(\mathrm{S}_{6}\right)$ & 0.0425 \\
& & O\&M Cost $\left(\mathrm{S}_{7}\right)$ & 0.1232 \\
Socio-Environmental $\left(\mathrm{C}_{3}\right)$ & \multirow{3}{*}{0.4286} & Rutrient Removal Efficiency $\left(\mathrm{S}_{9}\right)$ & 0.1334 \\
& & Social Acceptance $\left(\mathrm{S}_{10}\right)$ & 0.1350 \\
& & Tariff $\left(\mathrm{S}_{11}\right)$ & 0.0668 \\
& & Feasibility $\left(\mathrm{S}_{12}\right)$ & 0.0840 \\
& & &
\end{tabular}

The regulatory agency is responsible for implementing laws and regulations, as well as checking the compliance of establishments. Financial $(0.3570)$ has the highest weight, followed by implementability (0.3513) and socio-environmental (0.2917). O\&M cost $(0.1589)$ received the highest weight among the sub-criteria. This may be attributed to the effect of O\&M costs in the amount the consumers have to pay for treatment services [1, 3]. Maturity of technology (0.1319) and nutrient removal efficiency $(0.1301)$ ranked highest based from its respective criterion. Due to the grace period allotted for establishments to comply with the current standards, the sector prefers technologies with capability to meet the standards.

Table 5. The Weights of Criteria and Sub-criteria for the Regulatory Agency

\begin{tabular}{cccc} 
Criteria & Weight & Sub-Criteria & Weight \\
\hline \multirow{3}{*}{ Implementability $\left(\mathrm{C}_{1}\right)$} & \multirow{2}{*}{0.3513} & Robustness $\left(\mathrm{S}_{1}\right)$ & 0.0541 \\
& & Energy Requirement $\left(\mathrm{S}_{2}\right)$ & 0.0588 \\
& & Ease of Operation $\left(\mathrm{S}_{3}\right)$ & 0.0698 \\
& & Maturity of Technology $\left(\mathrm{S}_{4}\right)$ & 0.1319 \\
Financial $\left(\mathrm{C}_{2}\right)$ & \multirow{2}{*}{0.3570} & Space Requirement $\left(\mathrm{S}_{5}\right)$ & 0.0368 \\
\hline & & Capital Cost $\left(\mathrm{S}_{6}\right)$ & 0.0469 \\
& & O\& M Cost $\left(\mathrm{S}_{7}\right)$ & 0.1589 \\
& & Return of Investment $\left(\mathrm{S}_{8}\right)$ & 0.1511 \\
\hline Socio-Environmental $\left(\mathrm{C}_{3}\right)$ & 0.2917 & Nutrient Removal Efficiency $\left(\mathrm{S}_{9}\right)$ & 0.1301 \\
& & Social Acceptance $\left(\mathrm{S}_{10}\right)$ & 0.0511 \\
& & Tariff $\left(\mathrm{S}_{11}\right)$ & 0.0218 \\
& & Feasibility $\left(\mathrm{S}_{12}\right)$ & 0.0887 \\
\hline
\end{tabular}

The industry sector provides treatment services to the community and is responsible for complying with the stringent requirements implemented by the regulatory agency. From the results in Table 6, space requirement (0.2010), under implementability 
(0.5742), heavily affected their decision due to limited land area for installation, especially in urban areas. O\&M cost (0.0961) ranked highest under financial due to the additional cost incurred from retrofitting or installing additional treatment facilities. Lastly, tariff (0.0841) was the most preferred sub-criterion under socio-environmental criterion. This is because the operating and maintenance costs for installing treatment facilities are recovered when consumers are willing to pay for the services rendered $[1,3]$.

Table 6. The Weights of Criteria and Sub-criteria for the Industry Sector

\begin{tabular}{cccc} 
Criteria & Weight & Sub-Criteria & Weight \\
\hline \multirow{3}{*}{ Implementability $\left(\mathrm{C}_{1}\right)$} & \multirow{3}{*}{0.5742} & Robustness $\left(\mathrm{S}_{1}\right)$ & 0.0912 \\
& & Energy Requirement $\left(\mathrm{S}_{2}\right)$ & 0.0900 \\
& & Ease of Operation $\left(\mathrm{S}_{3}\right)$ & 0.0857 \\
& & Maturity of Technology $\left(\mathrm{S}_{4}\right)$ & 0.1064 \\
Financial $\left(\mathrm{C}_{2}\right)$ & \multirow{2}{*}{0.2021} & Space Requirement $\left(\mathrm{S}_{5}\right)$ & 0.2010 \\
\hline & & Capital Cost $\left(\mathrm{S}_{6}\right)$ & 0.0514 \\
& & O\& M Cost $\left(\mathrm{S}_{7}\right)$ & 0.0961 \\
Socio-Environmental $\left(\mathrm{C}_{3}\right)$ & \multirow{3}{*}{0.2237} & Rutrient Removal Efficiency $\left(\mathrm{S}_{9}\right)$ & 0.0546 \\
& & Social Acceptance $\left(\mathrm{S}_{10}\right)$ & 0.0442 \\
& & Tariff $\left(\mathrm{S}_{11}\right)$ & 0.0367 \\
& & Feasibility $\left(\mathrm{S}_{12}\right)$ & 0.0841 \\
& & &
\end{tabular}

After calculated the grey relational coefficients using Equations 5 to 8, the best attributes were identified and highlighted in Table 7 . For instance, in the academe, O\&M cost is the best attribute of 5BP (A1) since it is the closest to the reference sequence. On the other hand, most of the sub-criteria of SBR $\left(\mathbf{A}_{2}\right), \mathrm{A}^{2} \mathrm{O}\left(\mathbf{A}_{3}\right)$ and MBR $\left(\mathbf{A}_{4}\right)$ are considered the best attributes.

Table 7. Grey Relational Coefficients

\begin{tabular}{|c|c|c|c|c|c|c|c|c|c|c|c|c|}
\hline \multirow[t]{2}{*}{ Alt } & \multicolumn{12}{|c|}{ Sub-criteria } \\
\hline & 1 & 2 & 3 & 4 & 5 & 6 & 7 & 8 & 9 & 10 & 11 & 12 \\
\hline \multicolumn{13}{|c|}{ ACADEME } \\
\hline $\mathbf{X}_{\mathbf{0}}$ & 1.00 & 1.00 & 1.00 & 1.00 & 1.00 & 1.00 & 1.00 & 1.00 & 1.00 & 1.00 & 1.00 & 1.00 \\
\hline $\mathbf{A}_{1}$ & 0.38 & 0.54 & 0.50 & 0.56 & 0.33 & 0.47 & 0.71 & 0.43 & 0.67 & 0.33 & 0.33 & 0.33 \\
\hline $\mathbf{A}_{2}$ & 1.00 & 0.64 & 1.00 & 0.71 & 0.58 & 1.00 & 1.00 & 0.60 & 0.33 & 1.00 & 1.00 & 1.00 \\
\hline A3 & 0.38 & 1.00 & 0.67 & 1.00 & 0.44 & 0.78 & 1.00 & 1.00 & 0.44 & 0.56 & 0.67 & 0.67 \\
\hline $\mathbf{A}_{4}$ & 0.33 & 0.33 & 0.33 & 0.33 & 1.00 & 0.33 & 0.33 & 0.33 & 1.00 & 0.33 & 0.33 & 0.36 \\
\hline \multicolumn{13}{|c|}{ REGULATORY AGENCY } \\
\hline $\mathbf{X}_{\mathbf{0}}$ & 1.00 & 1.00 & 1.00 & 1.00 & 1.00 & 1.00 & 1.00 & 1.00 & 1.00 & 1.00 & 1.00 & 1.00 \\
\hline $\mathbf{A}_{1}$ & 0.33 & 0.33 & 0.33 & 0.50 & 0.33 & 0.50 & 1.00 & 0.50 & 0.33 & 0.33 & 0.33 & 0.33 \\
\hline $\mathbf{A}_{2}$ & 0.75 & 1.00 & 0.75 & 1.00 & 0.33 & 1.00 & 0.33 & 1.00 & 0.33 & 1.00 & 0.50 & 1.00 \\
\hline $\mathbf{A}_{3}$ & 0.43 & 0.50 & 0.43 & 0.33 & 1.00 & 1.00 & 0.33 & 0.33 & 0.55 & 0.40 & 0.50 & 0.50 \\
\hline $\mathbf{A}_{4}$ & 1.00 & 0.33 & 1.00 & 0.50 & 0.50 & 0.33 & 1.00 & 0.50 & 1.00 & 0.67 & 1.00 & 0.67 \\
\hline \multicolumn{13}{|c|}{ INDUSTRY } \\
\hline $\mathbf{X}_{\mathbf{0}}$ & 1.00 & 1.00 & 1.00 & 1.00 & 1.00 & 1.00 & 1.00 & 1.00 & 1.00 & 1.00 & 1.00 & 1.00 \\
\hline $\mathbf{A}_{1}$ & 1.00 & 0.63 & 0.67 & 0.43 & 0.33 & 1.00 & 0.67 & 0.33 & 1.00 & 0.41 & 0.41 & 0.38 \\
\hline $\mathrm{A}_{2}$ & 0.33 & 1.00 & 0.33 & 1.00 & 0.67 & 0.76 & 0.67 & 0.43 & 0.33 & 0.52 & 1.00 & 1.00 \\
\hline $\mathbf{A}_{3}$ & 0.43 & 0.63 & 1.00 & 0.43 & 0.57 & 0.62 & 1.00 & 1.00 & 0.56 & 0.33 & 0.41 & 0.38 \\
\hline $\mathrm{A}_{4}$ & 0.50 & 0.33 & 0.53 & 0.33 & 1.00 & 0.33 & 0.33 & 0.60 & 0.56 & 1.00 & 0.33 & 0.33 \\
\hline
\end{tabular}


The grey relational grades (GRG) of the alternatives were determined by combining the calculated weights from Tables $4-6$ and the grey relational coefficients from Table 7. Table 8 shows the preference of each sector on the optimal BNR technology to be installed in the Philippine setting. It was observed that the most preferred alternative has the most number of best attributes based on the grey relational coefficients in Table 7 .

Table 8. Ranking of Alternatives for the Academe, Regulatory Agency, and Industry Sectors.

\begin{tabular}{cccc} 
Rank & Academe & Regulatory Agency & Industry \\
\hline $\mathbf{1}$ & $\mathrm{SBR}(0.7910)$ & $\mathrm{SBR}(0.7409)$ & $\mathrm{SBR}(0.6926)$ \\
$\mathbf{2}$ & $\mathrm{A}^{2} \mathrm{O}(0.7242)$ & $\mathrm{MBR}(0.7230)$ & $\mathrm{A}^{2} \mathrm{O}(0.6178)$ \\
$\mathbf{3}$ & 5BP $(0.4759)$ & $5 \mathrm{BP}(0.4943)$ & $5 \mathrm{BP}(0.5669)$ \\
$\mathbf{4}$ & $\mathrm{MBR}(0.4757)$ & $\mathrm{A}^{2} \mathrm{O}(0.4615)$ & $\mathrm{MBR}(0.5485)$ \\
\hline
\end{tabular}

The academe considers SBR as the most preferred alternative. Feasibility, the most preferred sub-criterion overall based on calibrated FAHP and one of the best attributes based from GRA, significantly contributed to its overall ranking. Other best attributes of SBR are robustness, ease of operation, capital cost, O\&M cost, social acceptance, and tariff. On the other hand, MBR is the least preferred due to the performance of other sub-criteria. Only space requirement and nutrient removal efficiency are the best attributes.

For the regulatory agency, SBR is the optimal alternative. Two of the most preferred sub-criteria (maturity of technology and return of investment) are referred as its best attributes. The other best attributes are energy requirement, maturity of technology, capital cost, return of investment, social acceptance, and feasibility. $\mathrm{A}^{2} \mathrm{O}$ received the lowest ranking since space requirement and capital cost, its two best attributes, are the $2^{\text {nd }}$ and $3^{\text {rd }}$ least preferred sub-criteria considered in the selection of optimal BNR technology.

Lastly, the industry sector considers SBR as the most preferred alternative. SBR received the highest grade since it has many best attributes such as energy requirement, maturity of technology, return of investment, nutrient removal efficiency, and feasibility. MBR ranked least since the grey relational coefficients of most sub-criteria are far from the reference sequence.

It is observed that the ranking of alternatives of the regulatory agency from academe and industry is different. For the academe and industry sectors, $\mathrm{A}^{2} \mathrm{O}$ is the second most preferred, followed by $5 \mathrm{BP}$ and $\mathrm{MBR}$. $\mathrm{A}^{2} \mathrm{O}$ has O\&M costs and return of investment as its best attributes, which are the most preferred under financial criterion of the academe and industry sector, respectively. Meanwhile, MBR is the second most preferred alternative for the regulatory agency, followed by $5 \mathrm{BP}$ and $\mathrm{A}^{2} \mathrm{O}$. O\&M cost and nutrient removal efficiency are the two most preferred sub-criteria that increased the overall ranking of MBR. Other attributes were robustness, ease of operation, and tariff.

Overall, the three sectors have the same preference on SBR as the optimal BNR technology. Based on the grey relational coefficients (Table 7), all sectors agreed that feasibility is its best feature while space requirement and nutrient removal efficiency are the worst features. Despite high prioritization of the academe and industry sectors on space requirement and the regulatory agency on nutrient removal (Tables $4-6$ ), the weight of the other best features contributed to the overall ranking of SBR. 


\section{Conclusions}

The study aims to know the perspective of the three sectors (academe, regulatory agency, and industry) in the selection of optimal BNR technology in the Philippines. This is determined by utilizing calibrated fuzzy AHP and grey relational analysis (GRA). The alternatives evaluated were $\mathrm{A}^{2} \mathrm{O}, 5$-stage Bardenpho, SBR, and MBR. The criteria and subcriteria were determined through literature review and focus group discussion with experts with background on wastewater treatment, while the alternatives were selected based on literature review. Calibrated fuzzy AHP is used to calculate the global weights of the criteria and sub-criteria, which were used to compute the grey relational grade of alternatives. Results showed that different prioritization of each sector affected the ranking of the alternatives. The academe selects the optimal BNR technology based on how it can be operated in real applications given several constraints. The regulatory agency prefers technologies that have been studied extensively and can meet the current effluent standards. The industry sector selects the optimal BNR technology that can be operated in limited space and based on the willingness of the community to pay for the sanitation services. Grey relational analysis was used to determine the best attributes and ranking of each alternative. It was observed that the most preferred alternative has the highest number of best attributes. Results showed that SBR is the optimal BNR technology for all sectors.

\section{Acknowledgement}

The authors would like to acknowledge the Department of Science and Technology Philippine Council for Industry, Energy and Emerging Technology Research and Development (DOST-PCIEERD) for the support given to project titled "Sustainable Wastewater Treatment Systems with Nutrient (SWAN) Recovery” (Project No. 04176).

\section{References}

[1] ARCOWA, Wastewater Management and Resouce Recovery in the Philippines: Current Status and Opportunities [Online]. Available:

http://seaknowledgebank.net/sites/default/files/wastewater_management_and_resource_r ecovery_in_Philippines_0.pdf [Accessed: March 2020].

[2] The International Water Association, Wastewater Report 2018: The Reuse Opportunity [Online]. Available:

https://reliefweb.int/sites/reliefweb.int/files/resources/OFID\%20Wastewater\%20report \%202018\%20screen.pdf [Accessed: March 2020].

[3] K. Andersson, A. Rosemarin, B. Lamizana, E. Kvarnström, J. McConville, R. Seidu, S. Dickin, and C. Trimmer, Sanitation, Wastewater Management, and Sustainability: From Waste Disposal to Resource Recovery, United Nations Environment Programme and Stockholm Environment Institute, 2016.

[4] C.M.J. Pausta, A.B. Beltran, A. Huelgas-Orbecido, M.A.B. Promentilla, and R.C.P. Eusebio, "A decision modelling approach for selection of biological nutrient removal systems for wastewater," Paper presented at $24^{\text {th }}$ Regional Symposium on Chemical Engineering, MATEC Web of Conferences, Semarang, Indonesia, 2018. doi: $10.1051 /$ matecconf $/ 201815603013$

[5] Department of Environment and Natural Resources, Water Quality Guidelines and General Effluent Standards of 2016 (DENR Administrative Order No. 2016-08), 2016 [Online]. Available: https://pab.emb.gov.ph/wp-content/uploads/2017/07/DAO-201608-WQG-and-GES.pdf [Accessed: January 2020]. 
[6] M. von Sperling, Activated Sludge and Aerobic Biofilm Reactors, IWA Publishing, London, United Kingdom, 2007.

[7] G. Tchobanoglous, M. Abu-Orf, H.D. Stensel, R. Tsuchihashi, F. Burton, and B. Pfrang, Wastewater Engineering: Treatment and Resource Recovery, $5^{\text {th }}$ Edition, McGraw-Hill Education, New York, United States, 2013.

[8] R.C. Eusebio, Y.-H. Cho, M. Sibag, H.-G. Kim, T.-H. Chung, and H.-S Kim, "Significant role of membrane fouling and microbial community on the performance of membrane bioreactor (MBR) system," Desalination and Water Treatment, Vol. 17, No. 1-3, pp. 90-98, 2010. doi: 10.5004/dwt.2010.1703

[9] Y. Chen, C. Peng, J. Wang, L. Ye, L. Zhang, and Y. Peng, "Effect of nitrate recycling ratio on simulataneous biological nutrient removal in a novel anaerobic/anoxic/oxic (A $2 / \mathrm{O})$-biological aerated filter (BAF) system," Bioresource Technolonogy, Vol. 102, pp. 5722-5727, 2011. doi: 10.1016/j.biortech.2011.02.114

[10] H. Xiang, X. Li, S. Hojae, Z. Shanfa, and Y. Dianhai, "Biological nutrient removal in a full scale anoxic/anaerobic/aerobic/pre-anoxic-MBR plant for low $\mathrm{C} / \mathrm{N}$ ratio municipal wastewater treatment," Chinese Journal of Chemical Engineering, Vol. 22, No. 4, pp. 447-454, 2014. doi: 10.1016/S1004-9541(14)60064-1

[11] G. Zeng, R. Jiang, G. Huang, M. Xu, and J. Li, "Optimization of wastewater treatment alternative selection by hierarchy grey relational analysis," Journal of Environmental Management, Vol. 82, No. 2, pp. 250-259, 2007. doi: 10.1016/j.jenvman.2005.12.024

[12] M.A.B. Promentilla, K.B. Aviso, and R.R. Tan, "A group fuzzy analytic network process to prioritize low carbon energy systems in the Philippines," Energy Procedia, Vol. 61, pp. 808-811, 2014. doi: 10.1016/j.egypro.2014.11.970.

[13] R.R. Tan, K.B. Aviso, A.P. Huelgas, and M.A.B. Promentilla, "Fuzzy AHP approach to selection problems in process engineering involving quantitative and qualitative aspects," Process Safety and Environmental Protection, Vol. 92, No. 5, pp. 467-475, 2014. doi: 10.1016/j.psep.2013.11.005.

[14] M.A.B. Promentilla, J.I.B. Janairo, D.E.C. Yu, C.M.J. Pausta, A.B. Beltran, A.P. Huelgas-Orbecido, J.F.D. Tapia, K.B. Aviso, and R.R. Tan, "A stochastic fuzzy multicriteria decision-making model for optimal selection of clean technologies." Journal of Cleaner Production, Vol. 183, pp. 1289-1299, 2018. doi: 10.1016/j.jclepro.2018.02.183

[15] A.R. Karimi, N. Mehrdadi, S. J. Hashemian, G.R. Nabi Bidhendi, and R. TavakkoliMoghaddam, "Selection of wastewater treatment process based on the analytical hierarchy process and fuzzy analytical hierarchy process methods," International Journal of Environmental Science \& Technology, Vol. 8, No. 2, pp. 267-280, 2011. doi: 10.1007/BF03326215

[16] S.A. Ghassemi, and S. Danesh, "A hybrid fuzzy multi-criteria decision making approach for desalination process selection," Desalination, Vol. 313, pp. 44-50, 2013. doi: 10.1016/j.desal.2012.12.008.

[17] A. Karimi, B. Ahmadpour, and M.R. Marjani, "Using the fuzzy grey relational analysis method in wastewater treatment process selection," Iranian Journal of Health, Safety \& Environment, Vol. 5, No. 3, pp. 1041-1050, 2018 [Online]. Available: http://www.ijhse.ir/index.php/IJHSE/article/view/325.

[18] R.C.P. Eusebio, A.P. Huelgas-Orbecido, and M.A.B. Promentilla, "Optimal selection of desalination systems using fuzzy AHP and grey relational analysis," Chemical Engineering Transactions, Vol. 52, pp. 649-654, 2016. doi: 10.3303/CET1652109.

[19] M. Ilangkumaran, G. Sakthivel, and V. Sasirekha, "Waste water treatment technology selection using FAHP and GRA approaches, ” International Journal of Environment and Waste Management, Vol. 14, No. 4, pp. 392-413, 2014. doi: 10.1504/IJEWM.2014.066594 
[20] J.W.K. Chan and T.K.L. Tong, "Multi-criteria material selections and end-of-life product strategy: Grey relational analysis approach," Materials \& Design, Vol. 28, No. 5, pp. 1539-1546, 2007. doi: 10.1016/j.matdes.2006.02.016.

[21] M. Braglia, R. Gabbrielli, and D. Miconi, "Material handling device selection in cellular manufacturing." Journal of Multi-Criteria Decision Analysis, Vol. 10, No. 6, pp. 303315, 2001. doi: 10.1002/mcda.310.

[22] F. Dweiri and F.M. Al-Oqla, "Material selection using analytical hierarchy process," International Journal of Computer Applications in Technology, Vol. 26, No. 4, pp. 182189, 2006. doi: 10.1504/IJCAT.2006.010763.

[23] P.O. Akadiri, P.O. Olomolaiye, and E.A. Chinyio, "Multi-criteria evaluation model for the selection of sustainable materials for building projects," Automation in Construction, Vol. 30, pp. 113-123, 2013. doi: 10.1016/j.autcon.2012.10.004.

[24] C.-C. Yang and B.S. Chen, "Supplier selection using combined analytical hierarchy process and grey relational analysis," Journal of Manufacturing Technology Management, Vol. 17, No. 7, pp. 926- 941, 2006. doi: 10.1108/17410380610688241.

[25] C. Kahraman, U. Cebeci, and Z. Ulukan, "Multi-criteria supplier selection using fuzzy AHP," Logistics Information Management, Vol. 16, No. 6, pp. 382-394, 2003. doi: 10.1108/09576050310503367.

[26] P.J.M. van Laarhoven, and W. Pedrycz, "A fuzzy extension of Saaty's priority theory," Fuzzy Sets and Systems, Vol. 11, pp. 229-241, 1983. doi: 10.1016/S01650114(83)80082-7.

[27] J.L. Deng, “Control problems of grey systems," Systems \& Control Letters, Vol. 1, No. 5, pp. 288-294, 1982. doi: 10.1016/S0167-6911(82)80025-X

[28] Y. Kuo, T. Yang, and G.-W. Huang, "The use of grey relational analysis in solving multiple attribute decision-making problems," Computers \& Industrial Engineering, Vol. 55, No. 1, pp. 80-93, 2008. doi: 10.1016/j.cie.2007.12.002.

[29] M.S. Pakkar, "An integrated approach to grey relational analysis, analytical hierarchy process and data envelopment analysis," Journal of Centrum Cathedra, Vol. 9, No. 1, pp. 71-86, 2016. doi: 10.1108/JCC-08-2016-0005.

[30] G.R. Pophali, A.B. Chelani, and R.S. Dhodapkar, "Optimal selection of full scale tannery effluent treatment alternative using integrated AHP and GRA approach," Expert Systems with Applications, Vol. 38, No. 9, pp. 10889-10895. doi: 10.1016/j.eswa.2011.02.129 